\title{
New dietary observations on Melanerpes flavifrons (Aves, Picidae): nectar consumption and possible pollination of two inflorescences
}

\author{
Estevão Freitas Santos ${ }^{1 *}$ \\ Jayrson Araújo de Oliveira ${ }^{2}$ \\ ${ }^{1}$ Projeto Avifauna de Goiás, CEP 74.270-170, Goiânia - GO, Brasil \\ ${ }^{2}$ Universidade Federal de Goiás, Goiânia - GO, Brasil \\ * Corresponding author \\ estevaobirding19@gmail.com
}

Submetido em 07/06/2021

Aceito para publicação em 08/09/2021

\section{Resumo}

Novas observações acerca da dieta de Melanerpes flavifrons (Aves, Picidae): consumo de néctar e possível polinização de duas inflorescências na Mata Atlântica do Brasil Central. A despeito dos hábitos predominantemente insetívoros dos pica-paus, uma espécie em particular, o benedito-de-testa-amarela (Melanerpes flavifrons), se destaca por sua dieta bastante frugívora e discrepante. Neste estudo, reportamos duas observações na Mata Atlântica de Goiás de consumo de néctar por M. flavifrons, que correspondem aos primeiros registros documentados desse hábito no Brasil, notadamente, nas flores de Inga ingoides e Combretum fruticosum. O comportamento chama à atenção pela possibilidade de polinização envolvida no processo, denotando uma demanda possivelmente maior de néctar pelas aves, no interior do país, durante a época mais seca do ano.

Palavras-chave: Combretum fruticosum; Inga ingoides

\section{Abstract}

Despite the predominant insectivorous habits of woodpeckers, the Yellow-fronted Woodpecker (Melanerpes flavifrons) stands out for its primarily frugivorous diet. In this study, we report two observations made in the Atlantic Forest of Goiás regarding nectar consumption by $M$. flavifrons. These are the first documented records of this habit in Brazil for the flowers of Inga ingoides and Combretum fruticosum. This behavior suggests that pollination might be involved in the process and there is possibly a greater demand for nectar by birds in the interior of the country during the driest period of the year.

Key words: Combretum fruticosum; Inga ingoides 
Woodpeckers (Picidae) are widely distributed birds in the Neotropical region (SICK, 1997), where they are represented by 95 species (SHORT, 1985) and exhibit a diverse array of behavioral, ecological, and morphological traits. They are mostly recognized by their insectivorous habits, although some are fond of fruits (WINKLER et al., 1995; WINKLER; CHRISTIE, 2002; ROCCA et al., 2006). In fact, many neotropical species enjoy vegetable matter, such as those in the genera Campephilus, Celeus, Colaptes, Melanerpes, Veniliornis and Piculus (MOOJEN et al., 1941; SCHUBART et al., 1965; SICK, 1997; FRANCISCO; GALETTI, 2001; MIKITCH, 2002; PIZO, 2004; TUBELIS, 2007; VASCONCELOS et al., 2008), and seem to consume more of these resources during the winter (SICK, 1997).

The Yellow-fronted Woodpecker (Melanerpes flavifrons) is one of the most attractive, colorful, and strepitous representatives of the family and exhibits noteworthy social habits (SICK, 1997; SIGRIST, 2014; WINKLER et al., 2020). It is endemic to the Atlantic Forest (VALE et al., 2018) and occurs from southern Bahia to Rio Grande do Sul, as well as in Paraguay, Argentina, and locally in central Brazil (SICK, 1997; WINKLER et al., 2020). It includes a variety of items in its diet, such as arthropods, fruits, seeds, and even sugary water (WINKLER et al., 2020). Examples of fruits it consumes are those of Cecropia pachystachya (MARCONDES-MACHADO; ARGEL-DE-OLIVEIRA, 1988; MIKITCH, 2002) and Cabralea canjerana (PIZO, 1997), and it is one of the most frugivorous woodpeckers in southeastern Brazil (PARRINI, 2015).

Despite copious previous records of vegetable matter in the diet of this species, apparently M. flavifrons has still not been documented feeding on nectar of native flowers; although, there are a few comments of nectar ingestion in the literature (e.g., SICK, 1997; PARRINI, 2015). Contrastingly, other species of the genus (e.g., Gila Woodpecker, M. uropygialis) are known to seek nectar(WINKLER; CHRISTIE, 2002). Here, we present the first documented records of $M$. flavifrons feeding on the flower nectar of two species native to Brazil, as well as the possibility that pollination is involved in this activity.

Two excursions were conducted. On June 27, 2019, E.F.S. visited the Córrego Taquari riparian forest within the private area of Rancho Sabiá $\left(17^{\circ} 04^{\prime} \mathrm{S} 49^{\circ} 35^{\prime} \mathrm{W}\right)$ (Area 1) in Varjão, southwestern Goiás, Brazil. E.F.S. and J.A.O. went on a second excursion on May 27, 2021, to private farmland next to Parque Estadual Altamiro de Moura Pacheco (163'ㅇ 490' W) (Area 2 ) in Goianápolis. The vegetation matrix of both areas is mainly comprised of pastures and orchards on farms, and patches of semideciduous and deciduous forests, within Atlantic Forest sensu latissimo, i.e., in the former Mato Grosso de Goiás that is now almost completely gone (WILLIS, 1992; IBGE, 1993; OLIVEIRA-FILHO; RATTER, 1995; OLIVEIRA-FILHO et al., 2006; NEVES et al., 2017).

We recorded Yellow-fronted Woodpeckers visiting the flowers of two species of canopy plants native to central Brazil, Inga ingoides (Rich.) Willd., a relatively tall arboreous legume, and Combretum fruticosum (Loefl.) Stuntz., a large liana that is widespread in the Neotropical region. The flowers of Inga are hermaphroditic with white stamens and a green corolla (KOPTUR, 1983; NETO et al., 2007). In Goiás, $I$. ingoides blooms for two to four months at the end of the dry season (between July and October). Combretum fruticosum has erect flowers in elongated inflorescences, which vary in color from green to yellow and orange (SCHEMSKE, 1980; GRYJ et al., 1990). It blooms from April to July in the study region.

In Area 1, a pair of M. flavifrons was observed foraging on an I. ingoides tree for about 4-5 minutes while it climbed up the trunk and insistently vocalized. Once, the female jumped to a horizontal branch in the periphery of the tree and landed immediately next to some flowers. The individual penetrated its acuminate bill amidst the stamens and appeared to reach the corolla and obtain nectar with its long tongue. This movement was repeated several times within a couple minutes, and two other flowers were visited before the pair flew away.

In Area 2, a group of five individuals of $M$. flavifrons (three males and two females) was fortuitously 
observed and spent almost $2 \mathrm{~h}$ around the flowers of $C$. fruticosum in the canopy of seasonal semideciduous forest (ca. $15 \mathrm{~m}$ high). All five individuals sought nectar, perching beside or on the inflorescences and using both the bill and the tongue to reach the nectaries (Figures 1 and 2). One female chased a Variable Oriole (Icterus pyrrhopterus) to visit a flower and one male scared away a Sayaca Tanager (Thraupis sayaca) from the treetop. All the individuals seem to have contacted the reproductive organs of the flowers. At the end of the process, they had their forehead, throat, and bill covered in reddish pollen.

It is not clear if the female Yellow-fronted Woodpecker observed feeding on nectar of I. ingoides in
Area 1 was also pollinating flowers, since the individual was not observed carrying pollen. However, it touched the nectaries and visited more than a single flower in a row, so it might have acted as a pollen vector. Inga is more regularly pollinated by bats and moths (KOPTUR, 1983), but this does not exclude other activities, including pollination by diurnal visitors, such as hummingbirds (KOPTUR, 1984; AMORIM et al., 2012), tanagers and icterids (pers. obs.).

Gryj et al. (1990) attested that perching birds are the main pollinators of $C$. fruticosum flowers, since they carry abundant pollen during usually long visits. As mentioned above, we observed all the individuals of $M$.

FIGURE 1: Map showing Area 1 (yellow icon) and Area 2 (red icon). Photos: Google Earth Pro.
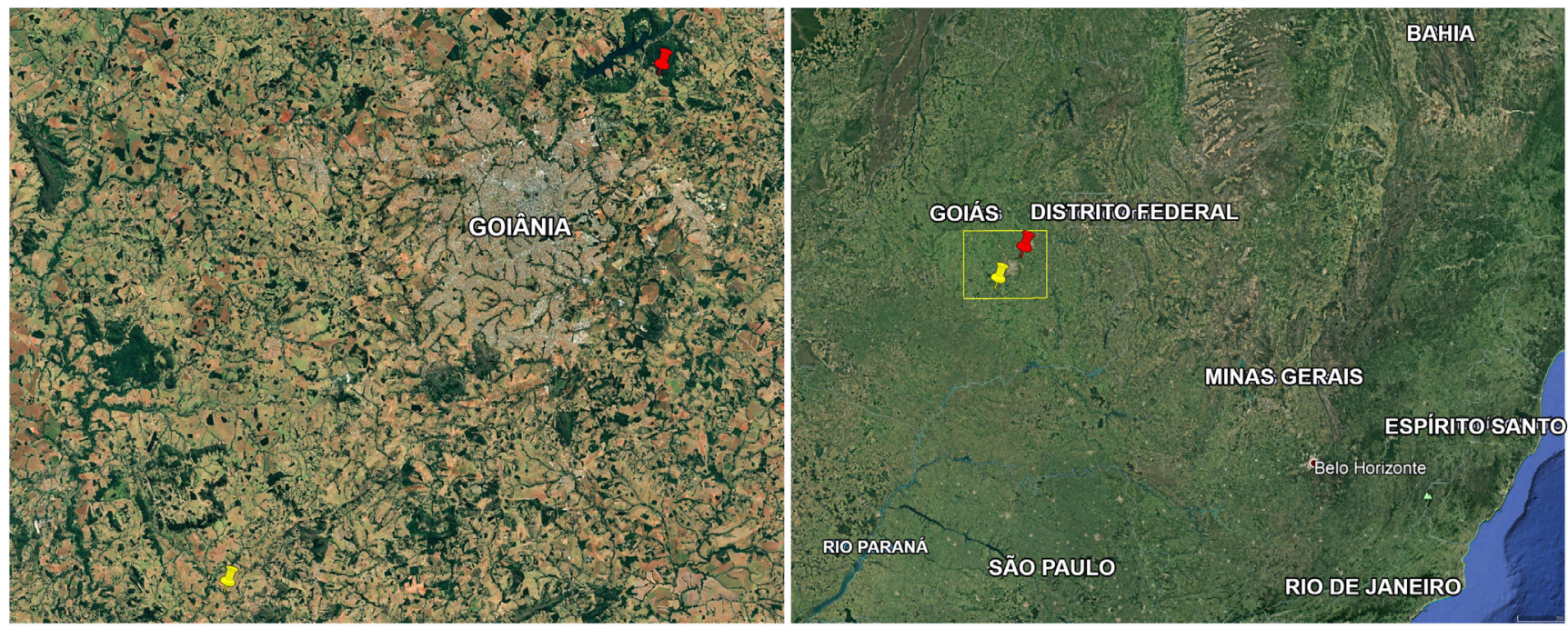

FIGURE 2: A male individual of Melanerpes flavifrons feeding on the nectar of Combretum fruticosum. Photos: Estevão F. Santos.
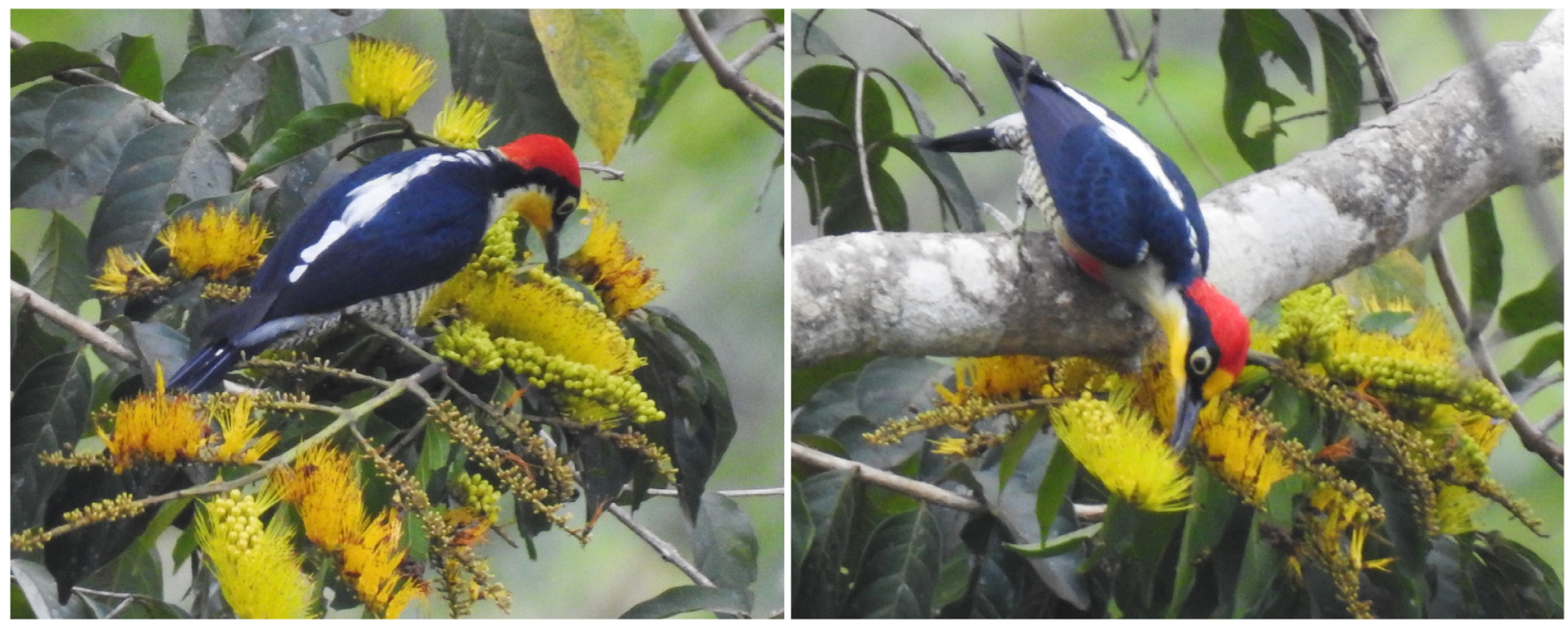
flavifrons dusted in pollen of $C$. fruticosum during their 2-hour visit to this plant, and the pollen was on their faces when they left one inflorescence and headed to another. The transportation of pollen grains and multiple visits suggest that $M$. flavifrons contributes to pollinating this species.

Indeed, other species of woodpeckers, including other Melanerpes, have also been observed feeding on the nectar of Combretum species. Gryj et al. (1990) listed M. chrysogenis as a visitor of $C$. fruticosum in Costa Rica, and Silva and Rubio (2007) observed M. candidus visiting C. lanceolatum in the Brazilian Pantanal. Thus, these observations suggest that the nectivorous habits of Melanerpes are likely much more common, including in other plant species with a perching-bird pollination syndrome.

Rocca et al. (2006) suggested that moving from sipping fruit juice to feeding on nectar is a relatively simple step for woodpeckers, due to their morphological attributes. Furthermore, we postulate that the certain demand for nectar among woodpeckers and other birds, at least in the region, perhaps involves seasonality. Both of our observations were made during dry periods of the year (May and July), when fleshy fruits are generally scarce. Considering the frugivorous habits of $M$. flavifrons, we assume that this resource scarcity in the winter favors a more regular search for nectar, which could also increase the obtainment of nutrients during periods of food deficiency. Such patterned behavior has also been postulated for events of flower consumption by insectivorous bird species, which may increase their search for this resource during the dry season when food is scarce (see GONSIOROSKI et al., 2021).

We suggest making more observations in Brazil of avian floral visitors, especially perching birds, for both species of plants. Systematic observations will provide a better understanding of the benefits of these visits to the birds and the reproductive and phenological systems of the plants. Ultimately, this data would contribute to increasing our knowledge of the natural history of these species and could contribute to habitat conservation and restoration. Since many woodpeckers are fond of "plant juice" additional observations could corroborate the importance of this resource for the group, especially during periods of food scarcity.

\section{Acknowledgements}

We sincerely thank Ricardo Parrini and Marcelo F. de Vasconcelos for carefully reviewing an earlier draft of this paper, and two anonymous reviewers for their suggestions and corrections. We also thank the proprietors of the private areas we visited for granting us free access. E. F. Santos thanks Luigi Seronni for the company during fieldwork on July 27.

\section{References}

AMORIM, F. W.; GALETTO, L.; SAZIMA, M. Beyond the pollination syndrome: nectar ecology and the role of diurnal and nocturnal pollinators in the reproductive success of Inga sessilis (Fabaceae). Plant Biology, Dundee, v. 15, p. 317-327, 2012.

FRANCISCO, M. R.; GALETTI, M. Frugivoria e dispersão de sementes de Rapanea lancifolia (Myrsinaceae) por aves numa área de cerrado do Estado de São Paulo, sudeste do Brasil. Ararajuba, Londrina, v. 9, p. 13-19, 2001.

GONSIOROSKI, G.; SAZIMA, I.; SILVA, M. A. R.; UBAID, F. K. Blooming meal: flower eating by the Blue-crowned Trogon Trogon curucui. Biota Neotropica, Campinas, v. 21, n. 3, e20201154, 2021.

GRYJ, E.; MARTINEZ DEL RIO, C.; BAKER, I. Avian pollination and nectar use in Combretum fruticosum (Loefl.). Biotropica, Malden, v. 22, n. 3, p. 266-271, 1990.

IBGE. Mapa de Vegetação do Brasil. Rio de Janeiro: Fundação Instituto Brasileiro de Geografia e Estatística, Ministério da Agricultura, 1993. Disponível em: <https:/geoftp.ibge.gov.br/ informacoes_ambientais/vegetacao/mapas/brasil/vegetacao.pdf $>$.

KOPTUR, S. Flowering phenology and floral biology of Inga Fabaceae: (Mimosoideae). Systematic Botany, Laramie, v. 8, p. $354-368,1983$.

KOPTUR, S. Outcrossing and pollinator limitation of fruit set: breeding systems of Neotropical Inga trees (Fabaceae: Mimosoideae). Evolution, New York, v. 38, n. 5, p. 1130-1143, 1984.

MARCONDES-MACHADO, L. O.; ARGEL-DE-OLIVEIRA, M. M. Comportamento alimentar de aves em Cecropia (Moraceae) em Mata Atântica, no estado de São Paulo. Revista Brasileira de Zoologia, Curitiba, v. 4, p. 331-339, 1988.

MIKITCH, S. B. Consumo de frutos por quatro espécies de picapaus (Aves, Picidae) em remanescentes de Floresta Estacional Semidecidual do Sul do Brasil. Arquivos de Ciências Veterinárias e Zoologia da UNIPAR, Umuarama, v. 5, n. 2, p. 177-186, 2002.

MOOJEN, J.; CARVALHO, J. C.; LOPES, H. S. Observações sobre o conteúdo gástrico das aves brasileiras. Memórias do Instituto 
Oswaldo Cruz, Rio de Janeiro, v. 36, p. 405-444, 1941.

NETO, O. C.; FREITAS, A. V.; MACHADO, I. C. Ecologia da polinização de Inga striata (Benth.) (Leguminosae-Mimosoideae) em um remanescente de Mata Atlântica no Nordeste do Brasil. Revista Brasileira de Biociências, Porto Alegre, v. 5, p. 570-572, 2007.

NEVES, D. M.; DEXTER, K. G.; PENNINGTON, R. T.; VALENTE, A. S. M.; BUENO, M. L.; EISENLOHR, P. V.; FONTES, M. A. L.; MIRANDA, P. L. S.; MOREIRA, S. N.; REZENDE, V. L.; SAITER, F. Z.; OLIVEIRA-FILHO, A. T. Dissecting a biodiversity hotspot: the importance of environmentally marginal habitats in the Atlantic Forest Domain of South America. Diversity and Distributions, Stellenbosch, v. 23, p. 898-909, 2017.

OLIVEIRA-FILHO, A.; RATTER, J. A. A study of the origin of central Brazilian forests by the analysis of plant species distribution patterns. Edinburgh Journal of Botany, Edinburgh, v. 52, p. 141194, 1995.

OLIVEIRA-FILHO, A. T.; JARENKOW, J. A.; RODAL, M. J. N. Floristic relationships of seasonally dry forests of eastern South America based on tree species distribution patterns. In: PENNINGTON, R. T.; LEWIS, G. P.; RATTER, J. A. (Org.). Neotropical savannas and dry forests: plant diversity, biogeography and conservation. Boca Raton: CRC Press, 2006. p. 159-192.

PARRINI, R. Quatro estações - História natural das aves na Mata Atlântica: uma abordagem trófica. Rio de Janeiro: Technical Books, 2015.354 p.

PIZO, M. A. Seed dispersal and predation in two populations of Cabralea canjerana (Meliaceae) in the Atlantic Forest of southeastern Brazil. Journal of Tropical Ecology, Winchelsea, v. 13, p. 559-578, 1997.

PIZO, M. A. Frugivory and habitat use by fruit-eating birds in a fragmented landscape in southeast Brazil. Ornitologia Neotropical, Montreal, v. 15 (supl.), p. 117-126, 2004.

ROCCA, M. A.; SAZIMA, M.; SAZIMA, I. Woody woodpecker enjoys soft drinks: the blond-crested woodpecker seeks nectar and pollinates canopy plants in south-eastern Brazil. Biota Neotropica, Campinas, v. 6, n. 2, bn02606022006, 2006.

SCHEMSKE, D. W. Floral ecology and hummingbird pollination of Combretum farinosum in Costa Rica. Biotropica, Malden, v. 12, n. 3, p. 169-181, 1980.
SCHUBART, O.; AGUIRRE, A. C.; SICK, H. Contribuição para o conhecimento da alimentação das aves brasileiras. Arquivos de Zoologia, São Paulo, v. 12, p. 95-249, 1965.

SHORT, L. L. Neotropical-Afrotropical Barbet and Woodpecker radiations: a comparison. Ornithological Monographs, Sacramento, v. 36, p. 559-574, 1985.

SICK, H. Ornitologia brasileira. Rio de Janeiro: Ed. Nova Fronteira, 1997. 912 p.

SIGRIST, T. Guia de campo Avis Brasilis - Avifauna brasileira. São Paulo: Avis Brasilis, 2014. 608 p.

SILVA, J. F.; RUBIO, T. C. Combretum lanceolatum como recurso alimentar para aves no Pantanal. Revista Brasileira de Ornitologia, Belém, v. 15, p. 459-460, 2007.

TUBELIS, D. P. Fruit consumption by Colaptes campestris (Aves, Picidae) at Emas National Park, Brazil. Biotemas, Florianópolis, v. 20, n. 4, p. 131-133, 2007.

VALE, M. M.; TOURINHO, L.; LORINI, M. L.; RAJÃO, H.; FIGUEIREDO, M. S. L. Endemic birds of the Atlantic Forest: traits, conservation status, and patterns of biodiversity. Journal of Field Ornithology, Houston, v. 89, p. 193-206, 2018.

VASCONCELOS, M. F.; D’ANGELO-NETO, S.; VIANA, F. E. C. The white-browed woodpecker Piculus aurulentus (Temminck, 1821) (Aves: Picidae) as a potential seed disperser of Myrsine umbellata Mart. (Myrsinaceae). Lundiana, Belo Horizonte, v. 9, n. 2, p. 159-160, 2008.

WILLIS, E. O. Zoogeographical origins of Eastern Brazilian birds. Ornitologia Neotropical, Montreal, v. 3, p. 1-15, 1992.

WINKLER, H.; CHRISTIE, D. A. Family Picidae (woodpeckers). In: DEL HOYO, J.; ELLIOTT, A.; SARGATAL, J. (Ed.). Handbook of the birds of the world. Vol. 7. Barcelona: Lynx Edicions, 2002. p. 296-555.

WINKLER, H.; CHRISTIE, D. A.; BONAN, A. Yellow-fronted woodpecker (Melanerpes flavifrons), version 1.0. In: HOYO, J. del; ELLIOTT, A.; SARGATAL, J.; CHRISTIE, D. A.; JUANA, E. (Ed.). Birds of the World. Ithaca: Cornell Lab of Ornithology, 2020. Disponível em: <https://birdsoftheworld.org/bow/species/ yefwoo1/cur/introduction>.

WINKLER, H.; CHRISTIE, D. A.; NURNEY, D. Woodpeckers: an identification guide to the woodpeckers of the world. Boston: Houghton Mifflin Company, 1995. 406 p. 